\title{
Ontem, hoje, amanhã: a unidade criadora do tempo nos ofícios da profissão
}

\author{
Manuel Ferreira Patrício \\ Universidade de Évora \\ Portugal
}

[Comunicação ao Simpósio "Os ofícios da Profissão", organizado pela Associação dos Antigos Alunos da FCDEF-UP, 18 a 20 de Abril de 2001.]
Ontem, hoje, amanhã: a presença explícita do tempo. Palavras que fazem lembrar o poema de abertura de Os Quatro Quartetos de T. S. Elliot:

\section{O tempo passado e o tempo presente}

Fazem todos parte do tempo futuro.

Elliot apontava aqui, indubitavelmente, para a unidade do tempo. O tempo presente foi futuro, antes de ser o tempo que foi, para o tempo passado. O tempo presente tornou-se passado quando o tempo futuro se tornou presente.

Quando um tempo se instala desinstala outro tempo. Quando um tempo se instala, instala a realidade que lhe pertence. Ele não é, em rigor, essa realidade, mas é como se a fosse. Com efeito, a desinstalação dessa realidade é a desinstalação desse tempo e a desinstalação desse tempo é a desinstalação dessa realidade. Todavia, essa realidade é o que esse tempo traz consigo, não o que esse tempo é. O tempo, que mistério! Santo Agostinho disse dele, positivamente, esta coisa tão pouca e tão profunda, no Livro XI das Confissões: "O tempo é uma certa distensão”. É, pois, um certo movimento. Movimento elástico. Movimento de qualquer coisa. De algo. Que algo? O filósofo de Hipona não o disse. Nós podemos arriscar: movimento do Ser. Talvez, dizendo melhor: movimento de ser. Talvez ainda melhor: movimento do Ser a ser. Os alemães dizem: seiende. Os franceses dizem: étant. Os ingleses dizem: being. Nós também dizemos sendo. Mas dizemos, além disso, por sobre isso, a ser. Damos o ser na sua pulsação. No seu palpitar. No seu movimento vivo, real, de ser. Sendo não diz o mesmo que a ser. Sendo é a fixação, a paralisação, do movimento vivo de ser. $A$ ser é um movimento vivo na sua pulsação real. $A$ ser dá o movimento do tempo presente para o tempo passado e do tempo futuro para o tempo presente. O tempo presente vai, o tempo futuro chega. E logo vai. E logo outro chega. "O tempo é uma certa distensão".

Platão disse de outro modo, e talvez outra coisa: "O tempo é a imagem móvel da eternidade”. O filósofo de Atenas é um dualista integral. Há a Eternidade e há o Tempo. Há o Mundo Inteligível - Mundo da Eternidade - e há o Mundo sensível - Mundo do Tempo. Há o Conhecimento da Eternidade - o do Conceito - e há o Conhecimento do Tempo — o da Sensação. "O Tempo é a imagem móvel da Eternidade". O Tempo, no fim de contas, é ainda um modo da Eternidade: um modo de a Eternidade se mostrar, como imagem de si. Ao Conhecimento por sensação, que é o próprio do Tempo. O Tempo sentese. Sente-se como uma certa distensão. Por isso Santo Agostinho também disse do Tempo: se me perguntarem o que é, não sei; se não me perguntarem, sei. O que se sente não é respondível; só é respondível o que se pensa. O Tempo sente-se.

Todavia, não desistimos de o pensar. Aristóteles pensou-o assim: o Tempo é a medida do Movimento. Que o Tempo é indissociável do Movimento, eis o que parece óbvio. É ele o próprio Movimento? Ou é, como disse Aristóteles, a medida do Movimento? E nós perguntaremos: a medida do movimento ou aquilo que a medida do movimento mede? O Tempo é a sua própria medida, ou diferente da sua medida? Há entre o Tempo e o Espaço uma relação íntima. O relógio é uma extraordinária invenção humana que assenta nessa relação. Com efeito, o que o relógio faz é medir o Tempo por meio do Espaço. O que os 
ponteiros fazem é deslocar-se no espaço. A medida dessa deslocação é a medida do tempo. O Tempo é dado nessa, e por essa, medida.

A filosofia moderna - e também a ciência moderna - associou sempre o tempo e o espaço. Veja-se Newton. Veja-se Leibniz. Leibniz definiu luminosamente o Espaço e o Tempo. Eis como definiu o Espaço: "O Espaço é a ordem das coexistências". Eis como definiu o Tempo: "O Tempo é a ordem da sucessões". São belas definições, geniais definições. Todavia, ficam fora do que se define. Porque toda a coexistência é um instante do tempo, um ponto da Eternidade. E toda a sucessão é um movimento do Espaço ou do seja o que for que se move.

Se o que se move não for Espaço, então será Não-Espaço, In-Espaço. O Espírito, por exemplo, é In-Espaço. A mínima pulsação do Espírito também é movimento. A passagem de uma pulsação do Espírito a outra é sucessão. Há ali tempo. Tempo sem Espaço. Foi Kant quem viu claramente, na Crítica da Razão Pura, que o Tempo é mais fundo, mais originário, ontologicamente primeiro, que o Espaço. A simples experiência de sentir, a simples experiência de pensar, dá o Tempo. A experiência de ser a ser é a mais espantosamente originária e evidente experiência do Tempo. É a vivência íntima do Tempo. É a vivência do seu próprio ser a ser. Quando me sinto a ser não conheço o Tempo, não o sei definir: vivo-o. Eis o mistério do Tempo. Eis também a suprema e imediata e intuitiva transparência do Tempo.

Há uma obra de Fernando Namora com este título: Estamos no Vento. Nós diríamos, preferencialmente: Estamos no Tempo. Diríamos, melhor ainda: Somos no Tempo. Ou, finalmente: Somos Tempo. Ontem, Hoje, Amanhã. Somos, fomos, seremos. Somos o que fomos e somos o que seremos, como seremos o que fomos e o que somos. É a unidade do Tempo. Unidade criadora? O Tempo leva, o Tempo traz. Cria sempre. Cria quando leva e cria quando traz, cria quando destrói e cria quando constrói. É o presente que cria o passado: dá vida ao passado quando cria o passado. É o futuro que cria o presente: dá morte ao futuro no acto de dar vida ao presente. A Morte é a Vida e a Vida é a Morte: eis a essência contraditória, absurda, do Tempo. Teve razão Carlos de Oliveira quando escreveu: "Não há machado que corte /
A raiz ao pensamento. / Não há morte para o vento / Não há morte". Diremos: há só vida. Na unidade criadora do Tempo. O ser do Tempo é criar. Mesmo quando cria a Morte. Só há a Morte que o Tempo cria. A Morte é ainda uma criação do Tempo, uma obra do Tempo, uma obra viva do Tempo. Tudo é vida. Não há Morte.

Que é que, em nós, faz do passado algo vivo? É a lembrança. É a memória. A lembrança, a memória: a grande potência criadora da alma portuguesa. A lembrança de uma coisa com desejo dela é o que Duarte Nunes de Leão chamou a saudade, que Pascoaes veio a escrever com letra maiúscula. De que fez uma Deusa: a grande Deusa lusíada. A Saudade une e aduna o passado, o presente e o futuro. Lembra-se a coisa hoje e tem-se desejo dela hoje, mas com o ser todo no futuro. Ontem, Hoje, Amanhã. A grande Deusa lusíada é a Saudade do Futuro. Este é o segredo do pensamento futurista de António Vieira, Sampaio Bruno, Teixeira de Pascoaes e Fernando Pessoa. A Saudade é o Jano bifronte português: tem o rosto que olha para trás, e lembra; tem o rosto que olha para diante, e deseja. Deseja e anseia. Deseja, anseia e quer. $\mathrm{E}$ ao querer real segue-se a presença do objecto real, do objecto desejado, ansiado, amado. Foi assim que os Portugueses fizeram as Descobertas. E assim faremos as Descobertas que o futuro nos reserva, se as merecermos, se verdadeiramente as quisermos. É o milagre da unidade criadora do Tempo.

Mas nós dizemos ainda no título: a unidade criadora do Tempo nos ofícios da profissão.

Como profissão, temos a de professor. Somos a de professor. Somos professores.

Professor é um termo que tem a mesma origem que profissão. Vêm ambos os termos de pro-fateri: falar em prol, em favor de. O professor professa. O profissional professa. Quem professa crê. Crê e expõe a sua crença. Crê e expõe-se na sua crença. $\mathrm{O}$ agente de ensino cita e recita. O professor afirma a sua conviç̧ão. Assume-a. Expõe-se. Arrisca. Arrisca ser o que é, arrisca ser quem é. Temos uma profissão de risco. $\mathrm{O}$ que não arrisca está por engano nesta profissão. Pela boca morre o peixe, diz o povo. Mas também é pela boca que vive o peixe. Eis o retrato da nossa profissão. 
Coménio definiu assim aquela Casa que é o Templo onde celebramos a liturgia da nossa profissão, ou seja, a Escola: "A Escola é oficina de humanidade". A Escola é, portanto, a Casa onde exercemos o nosso ofício. Por isso é oficina.

Nem sempre houve ofícios. Os ofícios, o haver ofícios - eis uma extraordinária conquista da humanidade. Os ofícios são recortes do fazer no oceano imenso e indiferenciado do fazer. Os ofícios representam a estruturação ontológica do fazer. Oficial é o que tem um ofício e o exerce. Situa-se dentro de um domínio do fazer. Faz o que se faz ali. É ali que professa. É ali que se constitui e erige humanamente como um profissional.

Mas há o Tempo. E há o Ofício e os ofícios. O Ofício é da ordem da Eternidade. Os ofícios são da ordem do Tempo. A fidelidade ao Ofício tem de compaginar-se com a fidelidade aos ofícios. Os ofícios não são apenas a actividade do profissional. Os ofícios são, sobretudo, o dever do profissional: são as diversas profissões de fé no Ofício que o Tempo exige e traz. Há uma exigência inesgotável de ofícios no exercício da profissão.

Aqui se inscreve a dinâmica geracional. Aqui se inscrevem as tensões geracionais. Porque há os ofícios que estão já a deslizar para o passado e os ofícios que estão a chegar do futuro. E estão ambos ainda no presente. $\mathrm{E}$ os profissionais dos primeiros reagem aos profissionais dos segundos e os profissionais dos segundos reagem aos profissionais dos primeiros. Eis no que dá a incompreensão da lógica profunda da unidade criadora do Tempo. Eis no que resulta a incompreensão da verdade de que não há Morte e tudo é Vida.

Aliás, essa tensão existe e é activa dentro de cada um de nós. Porque cada um de nós é o profissional que já desliza irreversivelmente para o passado e é também aquele a que o futuro chega continuamente. Cada um de nós é o Tempo velho que se desinstala e o tempo novo que se instala. Contradição viva. Instalação que é a própria Vida. É o mistério, e é o milagre, da unidade criadora do Tempo nos ofícios da profissão.

Fixemos bem: estamos vivos enquanto não estivermos mortos. E estamos vivos enquanto o Tempo fluir em nós, enquanto formos uma realidade consciente em que o Tempo flui. Por isso o povo diz: velhos são os trapos. Precisamente: os trapos não são uma realidade consciente em que o Tempo flui. Todos nós, que aqui nos encontramos a pensar os ofícios da nossa profissão, ontem - hoje - amanhã, são os três tempos do compasso da vida. Uma vida dedicada ao outro: ao que se entrega a nós, que em nós confia, para a edificação da sua própria vida. Somos a unidade criadora dos três tempos do compasso. Se nos faltar um tempo, não há compasso. Qual de nós quer que a nossa vida de oficiais da nobre profissão de professor seja um compasso mutilado?!...

Sejamos, pois, dialecticamente, a unidade criadora do tempo nos ofícios da nossa profissão: contraditoriamente conservadora, actualistas e futuristas. Realizemos o milagre desta contradição. 